\title{
Effects of a Dietary Fermented Mushroom (Flammulina velutipes) By-Product Diet on Pork Meat Quality in Growing-Fattening Berkshire Pigs
}

\author{
Gyo-Moon $\mathrm{Chu}^{1}$, Suk-Nam Kang ${ }^{1}$, Jeong-Mo Yang ${ }^{2}$, Hoi-Yun Kim ${ }^{2}$ and Young-Min Song $^{2} *$ \\ ${ }^{1}$ Swine Science \& Technology Center, Gyeongnam National University of Science and Technology, Jinju 660-758, Korea, \\ ${ }^{2}$ Department of Animal Resources Technology, Gyeongnam National University of Science and Technology, Jinju 660-758, \\ Korea
}

\begin{abstract}
This study was carried out to investigate the effects of fermented mushroom (Flammulina velutipes) by-products on meat quality characteristics in fattening Berkshire pigs. The fermented diet mainly contained $40.0 \%$ mushroom by-products, $26.0 \%$ rice bran, and $20.0 \%$ formula feed and was fermented for $5 \mathrm{~d}$. The basal diet for the control (C) was substituted with 10\% (T1), 30\% (T2), $50 \%$ (T3), and 70\% (T4) fermented diet. Warner-Bratzler shear forces (WBSF) were significantly lower $(\mathrm{P}<0.05)$ in treatments than that in C. The meat color (lightness, redness, and yellowness) was significantly lower $(\mathrm{P}<0.05)$ in treatments than that in $\mathrm{C}$, whereas fat color (redness and yellowness) was significantly higher in treatments than that in $\mathrm{C}(\mathrm{P}<0.05)$. The compositions of palmitoleic acid and arachidonic acid were significantly higher $(\mathrm{P}<0.05)$ in $\mathrm{T} 4$ than that in $\mathrm{C}$. The amino acid composition of longissimus dorsi (LD) and the sensory evaluation of cooked meat were not affected by diet type. In conclusion, a diet of fermented mushroom by-products increased $\mathrm{pH}$ and backfat color, but decreased cooking loss, WBSF, and meat color of LD in growing-fattening Berkshire pigs.
\end{abstract}

(Key words : Berkshire pigs, Fermented diet, Meat quality, Mushroom by-products)

\section{INTRODUCTION}

Mushroom by-products have increased rapidly because of the increase in the Korean mushroom industry and it has been estimated to be more than 1.90 million ton per year (Kim et al., 2007). The media used for mushroom cultivation mainly contains cotton waste, corn cobs, and rice straw with a small amount of rice bran, wheat bran, beet pulp, cotton seed hull, cotton seed meal, and dried okra(Bae et al., 2006). Williams et al. (2001) reported that mushroom composition has approximately $80 \%$ nutrients available, because the mushroom growing process uses $20 \%$ of the nutrients in the cultivation media. Therefore, it is possible to use mushroom compost as an animal feedstuff.

Mushroom by-products can easily become contaminated by fungi and bacteria (Kim et al., 2007). These by-products start to decompose and grow harmful fungi after 2 to $3 \mathrm{~d}$ and 1 wk after disposal, respectively. They rapidly deteriorate because of the high content of moisture, which causes the growth of harmful microorganisms (Kwak et al., 2008).
Hence, mushroom by-products can be used as animal feedstuff when storage conditions are improved. Anaerobic fermentation using lactic acid bacteria improves storability, palatability, and nutrient values of feedstuff (Gao et al., 2008). The fermentation of mushroom by-products mixed with molasses, Lactobacillus plantarum, and Saccharomyces cervisiae decreases $\mathrm{pH}$ and increases lactic acid concentration and populations of lactic acid bacteria and yeast (Kwak et al., 2009). A fermented mushroom by-products diet using $L$. plantarium and $S$. cerevisiae increases crude protein (CP) concentration and total calories (Chu et al., 2012). Therefore, the mushroom by-products show improved storability and nutrient values when fermented by lactic acid bacteria and yeast.

Chu et al. (2012) found that a fermented mushroom by-product diet decreases growth performance and improves carcass grade in growing-fattening Berkshire pigs due to its low energy levels. Chu et al. (2012) studied the growth performance and carcass traits, but they did not study the effects of a fermented mushroom by-product diet on meat

\footnotetext{
* Corresponding author: Young Min Song, Department of Animal Resources Technology, Gyeongnam National University of Science and Technology, 150 Chilamdong, Jinju 660-758, Korea. Tel: +82-55-751-3282 Fax: +82-55-751-3689, E-mail: pigsong@gntech.ac.kr
} 
quality in Berkshire pigs. Therefore, this study was conducted as an extension experiment of the study of Chu et al. (2012) to investigate the effects of a fermented mushroom ( $F$. velutipes) by-product diet on the meat quality characteristics in growing-fattening Berkshire pigs.

\section{MATERIALS AND METHODS}

\section{Fermented diets and feeding experiment}

The feeding experimental design was described by $\mathrm{Chu}$ et al. (2012). The fermented mushroom by-product diet contained $40.0 \%$ mushroom by-products, $26.0 \%$ rice bran, $20.0 \%$ formula feed $2.0 \%$ barley stems, $2.0 \%$ sagebrush, $2.0 \%$ loess, $2.0 \%$ illite, $1.0 \%$ sweet potato vines, $1.0 \%$ purple sweet potato, $1.0 \%$ seame oil dregs, $1.0 \%$ perilla oil dregs, $1.0 \%$ balloon flower, $0.9 \%$ rye cobs, and $0.1 \%$ probiotics, respectively. These ingredients were mixed using a fermenter(Bio-Rea, Tong yang, Seoul, Korea) and the fermenting conditions were $40^{\circ} \mathrm{C}$ for $24 \mathrm{~h}$. The probiotics contained approximately $3.0 \times 10^{7}$ colony forming unit (cfu)/g L. plantarium and $2.0 \times 10^{7} \mathrm{cfu} / \mathrm{g} S$. cerevisiae. Then the mixture was transferred to anaerobic plastic containers and was fermented at room temperature for $4 \mathrm{~d}$. The average body weight $(\mathrm{BW})$ of the Berkshire pigs $(\mathrm{n}=225)$ used was $50.1 \pm 3.0 \mathrm{~kg}$ and they were fed the experimental diet until they reached an average BW of $105 \pm 2.8 \mathrm{~kg}$. Berkshire pigs were assigned to five dietary treatments such as the basal $\operatorname{diet}(\mathrm{C})$ and that substituted with 10\%(T1), 30\%(T2), 50\% (T3) or $70 \%$ (T4) fermented mushroom by-products. The nutritional values of the experimental diets are shown in Table 1.

\section{Meat sampling}

The 12 longissimus dorsi(LD) per treatment were chosen randomly. The $\mathrm{LD}$ (ribs 613) was cut off and kept at $5^{\circ} \mathrm{C}$ before being transported to the laboratory to determine meat quality.

\section{3. $\mathrm{pH}$, cooking loss, and Warner-Bratzler shear force (WBSF)}

A $5 \mathrm{~g}$ sample of LD was homogenized about $24 \mathrm{~h}$ postmortem in 10 volumes of distilled water using a Polytron homogenizer(MSE). $\mathrm{pH}$ values were determined using a Hanna HI 9025 pH meter (Woonsocket, RI, USA) with an Orion 8163 glass electrode (Beverley, MA, USA).

Cooking loss was determined as described by Honikel (1998). A $1.5 \mathrm{~cm}$ thick and about $80 \mathrm{~g} \mathrm{LD} \mathrm{muscle} \mathrm{samples}$ were put into polyethylene bags. The packages were heated in a water bath at $75^{\circ} \mathrm{C}$ for $1 \mathrm{~h}$ and then cooled at room temperature for $30 \mathrm{~min}$. The cooking loss percentage was determined using muscle weights taken before and after cooking.

WBSF was determined as described by Honikel (1998). The LD was cut into approximate cubes of $4 \mathrm{~cm} \times 2.5 \mathrm{~cm} \times$ $1.5 \mathrm{~cm}$ (i.e. length $\times$ width $\times$ height), and the WBSF of fresh samples was determined immediately. The samples were cooked in a water bath at $75^{\circ} \mathrm{C}$ until the internal temperature of the $\mathrm{LD}$ reached $70^{\circ} \mathrm{C}$. Then the samples were cooled for $4 \mathrm{~h}$ at $25^{\circ} \mathrm{C}$. The WBSF was measured using an Instron 3343 instrument (US/MX50, A\&D Co., Milpitas, CA, USA) equipped with one Warner-Bratzler shear blade (crosshead speed of $1 \mathrm{~mm} / \mathrm{sec}$ ).

\section{Meat and fat color}

Meat and fat color of LD were evaluated on freshly or cooked cut surfaces ( $3 \mathrm{~cm}$ thick slice) using a chroma meter CR-300 (Minolta, Osaka, Japan) after placing the samples at room temperature for $20 \mathrm{~min}$. Five color measurements were carried out across individual sample surfaces and the average of five replicates was expressed as CIE L*, CIE $a^{*}$, CIE b*, chroma and hue angle. The chroma meter was calibrated against a white tile $\left(\mathrm{L}^{*}=93.30, \mathrm{a}^{*}=0.32\right.$, and $\left.\mathrm{b}^{*}=0.33\right)$. The aperture was $8 \mathrm{~mm}$, illuminant D65 and $10^{\circ}$ standard observer. Chroma (saturation) was calculated as $\left(\mathrm{a}^{*^{2}}+\mathrm{b}^{*^{2}}\right)^{1 / 2}$, and hue angle was calculated as $\arctan b^{*} / a^{*}$ (Wyszcecki and Stiles, 1982).

\section{Fatty acid composition}

Meat fat was extracted from ground muscle using a modified Folch wash method as described by Ways and Hanahan (1964). Fatty acids were quantified as their fatty acid methyl esters and prepared by acid catalyzed methanolysis (Stantos et al., 1997). The fatty acid methyl esters in the hexane layer were analyzed on an Agilent chromatograph (Agilent 6890+, Agilent Technologies, Palo Alto, CA, USA) with a mass spectrometry detector and split $(50: 1)$ injector. The samples were methylated in duplicate 
and were injected twice into the gas liquid chromatography (GLC) column. The separation of the fatty acid methyl esters was performed on a HP-5MS capillary GLC column (HP, 30 $\mathrm{m} \times 0.32 \mathrm{~mm}$ i.d.; $0.25 \mathrm{~mm}$ film thickness) using helium as the carrier gas. The mass spectrometry interface and injector temperature were fixed at $270{ }^{\circ} \mathrm{C}$ and $260^{\circ} \mathrm{C}$, respectively. Oven temperature was $160^{\circ} \mathrm{C}$ at $2.5 \mathrm{~min}, 160 \sim 260^{\circ} \mathrm{C}$ at $4{ }^{\circ} \mathrm{C}$ $/ \mathrm{min}$ and $260^{\circ} \mathrm{C}$ at $5 \mathrm{~min}$. Data were recorded and analyzed on a ChemStation (G1701Ca version C.00).

\section{Amino acid composition}

A $100 \mathrm{mg}$ LD sample was added to $3 \mathrm{~mL} 6 \mathrm{~N}$ hydrochloric acid then packed in nitrogen gas. The packed samples were hydrolyzed at $110^{\circ} \mathrm{C}$ for $24 \mathrm{~h}$ and then removed from the hydrochloric acid gas. The enriched samples were added to $5 \mathrm{~mL}$ sodium citrate buffer and filtered through $0.2 \mu \mathrm{m}$ membrane filters. The amino acid composition was measured with an amino acid auto analyzer (Biochrom 20, Olympus, Tokyo, Japan).

\section{Sensory evaluation}

A total of 35 panelists were used, consisted mainly of students and staff members (Meat Science Laboratory, Gyeongnam National University of Science and Technology, Jinju, Korea) to evaluate sensory quality of the cooked samples. The sensory evaluations were performed in duplicate on each sample by the sensory panelists. Training of panelists was performed according to a sensory evaluation procedure (Meilgaard et al., 1991). The meat samples were cooked to an internal temperature $70^{\circ} \mathrm{C}$ in a water bath and were then cut into $10 \times 3 \times 25 \mathrm{~mm}^{3}$ pieces, placed on white plastic trays covered with aluminum foil, and served immediately to each panelist.

The cooked meat samples were evaluated for color $(1=$ very unacceptable; $9=$ very acceptable), off-flavor $(1=$ very weak; $9=$ very strong $),$ juiciness $(1=$ very dry; $9=$ very juicy), flavor ( $1=$ very unacceptable; $9=$ very acceptable), tenderness $(1=$ very tough; $9=$ very tender $)$, and total acceptability $(1=$ very unacceptable; $9=$ very acceptable $)$.

\section{Statistical Analyses}

Data were analyzed using the General Linear Model (GLM) procedure of SAS (1999) and significant differences among the means were determined using Duncan's multiple range test at $\mathrm{P}<0.05$ (Duncan, 1955).

\section{RESULTS}

\section{Proximate composition}

The fermented mushroom by-product diet decreased the nutritional values as dry matter (DM), crude protein (CP) and crude fat concentrations and metabolism energy (ME) values and increased crude fiber and ash concentrations of the feedstuff (Table 1).

\section{Physical-chemical characteristics}

The results of $\mathrm{pH}$, cooking loss and WBSF in LD are

Table 1. Chemical composition of the fermented mushroom by-product diets

\begin{tabular}{|c|c|c|c|c|c|c|c|c|c|c|}
\hline \multirow{3}{*}{ Items } & \multicolumn{10}{|c|}{ Treatments $^{1)}$} \\
\hline & \multirow{2}{*}{\multicolumn{2}{|c|}{$\frac{\mathrm{C}}{\text { Growing Fattening }}$}} & \multicolumn{2}{|c|}{$\mathrm{T} 1$} & \multicolumn{2}{|c|}{$\mathrm{T} 2$} & \multicolumn{2}{|c|}{ T3 } & \multicolumn{2}{|c|}{$\mathrm{T} 4$} \\
\hline & & & Growing & Fattening & Growing & Fattening & Growing & Fattening & Growing & Fattening \\
\hline $\mathrm{DM}^{2)}$ & 87.44 & 87.49 & 83.31 & 83.36 & 75.06 & 75.10 & 66.81 & 66.84 & 58.56 & 58.57 \\
\hline $\mathrm{CP}^{2)}$ & 14.15 & 15.34 & 13.38 & 14.45 & 11.85 & 12.68 & 10.31 & 10.91 & 8.78 & 9.14 \\
\hline Crude fat ${ }^{2)}$ & 6.27 & 6.41 & 5.91 & 6.04 & 5.19 & 5.29 & 4.47 & 4.54 & 3.76 & 3.80 \\
\hline Crude fiber $\left.{ }^{2}\right)$ & 3.06 & 2.98 & 3.30 & 3.23 & 3.78 & 3.72 & 4.25 & 4.21 & 4.73 & 4.71 \\
\hline $\mathrm{Ash}^{2)}$ & 4.97 & 4.78 & 5.03 & 4.86 & 5.15 & 5.01 & 5.26 & 5.17 & 5.38 & 5.32 \\
\hline $\mathrm{ME}^{3)}, \mathrm{Mcal} / \mathrm{Kg}$ & 3.26 & 3.28 & 3.10 & 3.12 & 2.77 & 2.79 & 2.45 & 2.42 & 2.13 & 2.13 \\
\hline
\end{tabular}

${ }^{1)}$ The basal diet was substituted with fermented mushroom (F. velutipes) by-products: C, no substitution; T1, 10\%; T2, 30\%; T3 50\%; and T4 $70 \%$.

${ }^{2)}$ Analytical values. 
shown in Table 2. The $\mathrm{pH}$ was significantly higher $(\mathrm{P}<0.05)$ in $\mathrm{T} 1, \mathrm{~T} 2$, and $\mathrm{T} 3$ than that in $\mathrm{C}$ and $\mathrm{T} 4$ as well as in $\mathrm{T} 2$ and $\mathrm{T} 3$ than that in T1. Cooking loss was significantly lower $(\mathrm{P}<0.05)$ in $\mathrm{T} 2, \mathrm{~T} 3$, and $\mathrm{T} 4$ than that in $\mathrm{C}$. Although WBSF of fresh meat and fresh fat were affected by the fermented diet, no effects were observed on WBSF of cooked meat. The WBSF of fresh meat was significantly $(\mathrm{P}<$ 0.05) lower in treated groups than that in $\mathrm{C}$, whereas no difference was observed among the treated groups. Moreover, WBSF of fresh meat was significantly lower $(\mathrm{P}<0.05)$ in
$\mathrm{T} 2$, T3, and T4 than that in $\mathrm{C}$ and was significantly lower $(\mathrm{P}<0.05)$ in $\mathrm{T} 4$ than that in $\mathrm{T} 2$ and $\mathrm{T} 3$.

\section{Meat color}

The results of meat and fat surface color are shown in Table 3. The overall parameter of meat surface color was significantly affected $(\mathrm{P}<0.05)$ by the fermented diet. The CIE L* (lightness) was significantly lower $(\mathrm{P}<0.05)$ in the fermented diet, and $\mathrm{T} 1$ and $\mathrm{T} 2$ were not significantly

Table 2. The effects of the fermented mushroom by-product diet on $\mathrm{pH}$, cooking loss, and Warner-Bratzler shear force in the longissimus dorsi (LD) of Berkshire pigs ${ }^{1)}$

\begin{tabular}{|c|c|c|c|c|c|c|}
\hline \multirow{2}{*}{ Item } & \multicolumn{5}{|c|}{ Treatment $^{2)}$} & \multirow{2}{*}{ SEM } \\
\hline & $\mathrm{C}$ & $\mathrm{T} 1$ & $\mathrm{~T} 2$ & $\mathrm{~T} 3$ & $\mathrm{~T} 4$ & \\
\hline $\mathrm{pH}$ & $5.64^{\mathrm{c}}$ & $5.73^{\mathrm{b}}$ & $5.89^{\mathrm{a}}$ & $5.84^{\mathrm{a}}$ & $5.68^{c}$ & 0.06 \\
\hline Cooking loss, $\%$ & $45.27^{\mathrm{a}}$ & $42.22^{\mathrm{ab}}$ & $41.27^{\mathrm{b}}$ & $41.10^{b}$ & $38.89^{\mathrm{c}}$ & 1.37 \\
\hline \multicolumn{7}{|c|}{ Warner-Bratzler shear force, $\mathrm{kg} / \mathrm{cm}^{2}$} \\
\hline Fresh meat & $5.91^{\mathrm{a}}$ & $2.78^{\mathrm{b}}$ & $2.49^{\mathrm{b}}$ & $2.81^{b}$ & $2.06^{\mathrm{b}}$ & 0.83 \\
\hline Cooked meat & 7.49 & 7.68 & 7.51 & 7.98 & 7.52 & 0.88 \\
\hline Fresh fat & $8.86^{\mathrm{a}}$ & $8.47^{\mathrm{ab}}$ & $8.17^{\mathrm{b}}$ & $7.98^{\mathrm{b}}$ & $7.70^{\mathrm{c}}$ & 3.44 \\
\hline
\end{tabular}

1) Twelve LD were analyzed in each treatment.

2) The basal diet was substituted with fermented mushroom (F. velutipes) by-products: C, no substitution; T1, 10\%; T2, 30\%; T3, 50\%, and T4, $70 \%$.

a,b,c Values in the same row with different superscripts differ at $\mathrm{P}<0.05$.

Table 3. The effects of the fermented mushroom by-product diet on the color of meat and backfat surface in longissimus dorsi (LD) of Berkshire pigs ${ }^{1)}$

\begin{tabular}{|c|c|c|c|c|c|c|}
\hline \multirow{2}{*}{ Item } & \multicolumn{5}{|c|}{ Treatment $^{2)}$} & \multirow{2}{*}{ SEM } \\
\hline & $\mathrm{C}$ & $\mathrm{T} 1$ & $\mathrm{~T} 2$ & $\mathrm{~T} 3$ & $\mathrm{~T} 4$ & \\
\hline \multicolumn{7}{|c|}{ Meat surface color ${ }^{3)}$} \\
\hline CIE L* & $64.07^{\mathrm{a}}$ & $55.07^{\mathrm{c}}$ & $59.40^{\mathrm{b}}$ & $58.00^{\mathrm{bc}}$ & $57.15^{\mathrm{bc}}$ & 3.57 \\
\hline $\mathrm{CIE} \mathrm{a*}$ & $10.77^{\mathrm{a}}$ & $7.93^{\mathrm{bc}}$ & $8.69^{\mathrm{b}}$ & $7.08^{\mathrm{c}}$ & $7.84^{\mathrm{bc}}$ & 1.64 \\
\hline CIE b* & $5.95^{\mathrm{a}}$ & $2.76^{\mathrm{c}}$ & $4.18^{\mathrm{b}}$ & $3.74^{\mathrm{bc}}$ & $3.17^{\mathrm{bc}}$ & 1.36 \\
\hline Chroma & $12.33^{\mathrm{a}}$ & $8.42^{\mathrm{b}}$ & $9.73^{\mathrm{b}}$ & $8.03^{\mathrm{b}}$ & $8.50^{\mathrm{b}}$ & 1.99 \\
\hline Hue angle & $28.51^{\mathrm{a}}$ & $19.57^{\mathrm{c}}$ & $25.08^{\mathrm{ab}}$ & $27.49^{\mathrm{a}}$ & $21.17^{\mathrm{bc}}$ & 4.95 \\
\hline \multicolumn{7}{|c|}{ Backfat surface color ${ }^{3)}$} \\
\hline CIE L* & 86.76 & 84.38 & 86.06 & 85.77 & 85.37 & 1.90 \\
\hline CIE $a^{*}$ & $2.74^{\mathrm{b}}$ & $2.69^{\mathrm{b}}$ & $3.67^{\mathrm{a}}$ & $3.57^{\mathrm{a}}$ & $3.24^{\mathrm{ab}}$ & 0.58 \\
\hline CIE b* & $3.19^{\mathrm{b}}$ & $2.99^{\mathrm{b}}$ & $5.28^{\mathrm{a}}$ & $5.31^{\mathrm{a}}$ & $5.35^{\mathrm{a}}$ & 0.80 \\
\hline Chroma & $4.22^{\mathrm{b}}$ & $4.06^{\mathrm{b}}$ & $6.44^{\mathrm{a}}$ & $6.40^{\mathrm{a}}$ & $6.26^{\mathrm{a}}$ & 0.93 \\
\hline Hue angle & $49.16^{\mathrm{bc}}$ & $48.56^{\mathrm{c}}$ & $55.13^{\mathrm{ab}}$ & $56.14^{\mathrm{a}}$ & $58.54^{\mathrm{a}}$ & 3.98 \\
\hline
\end{tabular}

1) Twelve LD were analyzed in each treatment.

2) The basal diet was substituted with fermented mushroom (F. velutipes) by-products: C, no substitution; T1, 10\%; T2, 30\%; T3, 50\% and T4, $70 \%$.

${ }^{3)} \mathrm{CIE} \mathrm{L*}$, black (0) to white (100) color scale; CIE a*, red (+) to green $(-)$ color scale; CIE b*, yellow (+) to blue $(-)$ color scale; Chroma, $\left(a^{* 2}+b^{* 2}\right)^{1 / 2}$ and hue angle, $b * / a *$.

${ }_{\mathrm{a}, \mathrm{b}, \mathrm{c}}$ Values in the same row with different superscripts differ at $\mathrm{P}<0.05$. 
Chu et. al. ; Fermented Mushroom By-product on Pork Quality

different from $\mathrm{T} 3$ and $\mathrm{T} 4$. The CIE $\mathrm{a}^{*}$ (redness) was significantly lower $(\mathrm{P}<0.05)$ in the treated groups than that in $\mathrm{C}$ and it was not different between $\mathrm{T} 2$ or $\mathrm{T} 3$ and $\mathrm{T} 1$ or T4. The CIE $b^{*}$ (yellowness) was significantly lower $(\mathrm{P}<$ 0.05) in the treated groups compared with that in $\mathrm{C}$ and it was not different among the treated groups. The CIE $\mathrm{L}^{*}$ of backfat surface color was similar across all treatments. CIE $\mathrm{a}^{*}$ was significantly higher $(\mathrm{P}<0.05)$ in $\mathrm{T} 2$ and $\mathrm{T} 3$ than that in $\mathrm{C}$ and it was not different in $\mathrm{T} 4$ compared with that in the other groups. CIE $\mathrm{b}^{*}$ and Chroma were significantly higher $(\mathrm{P}<0.05)$ in $\mathrm{T} 2, \mathrm{~T} 3$, and $\mathrm{T} 4$ than that in $\mathrm{C}$. Hue angle was significantly higher $(\mathrm{P}<0.05)$ in $\mathrm{T} 3$ and $\mathrm{T} 4$ than that in $\mathrm{C}$, and $\mathrm{T} 2$ was not different from the other groups.

\section{Fatty acid composition}

The results of fatty acid composition are shown in Table 4. Compositions of myristic acid, palmitic acid, stearic acid, oleic acid, linoleic acid, and linolinic acid were similar in all treatments. The proportion of palmitoleic acid and arachidonic acid were significantly higher $(\mathrm{P}<0.05)$ in $\mathrm{T} 4$ than that in $\mathrm{C}$. Although the proportions of saturated fatty
acid(SFA), unsaturated fatty acid(USFA), USFA/SFA, and SFA/USFA were not affected by diet type, the essential fatty acid composition was affected. Essential fatty acid composition was significantly higher $(\mathrm{P}<0.05)$ in $\mathrm{T} 4$ than that in $\mathrm{T} 1$ and $\mathrm{T} 2$.

\section{Amino acid composition}

The fermented mushroom by-product diet did not affect the composition of essential amino acids such as arginine, histidine, isoleucine, leucine, lysine, methionine, phenylalanine, threnonine, or valine. Additionally, the composition of unessential amino acids such as alanine, aspartic acid, cysteine, glutamic acid, glycine, proline, serine, and tyrosine were not affected by diet type (Table 5).

\section{Sensory evaluation}

The fermented mushroom by-products diet did not affect the sensory evaluation parameters such as, color, aroma, taste, tenderness, texture, juiciness, or acceptability (Table 6).

Table 4. The effects of the fermented mushroom by-product diet on the fatty acid composition in longissimus dorsi (LD) of Berkshire pigs ${ }^{1)}$

\begin{tabular}{lcccccc}
\hline \multirow{2}{*}{ Item } & \multicolumn{5}{c}{ Treatment $^{2}$} & \multirow{2}{*}{ SEM } \\
\cline { 2 - 5 } & $\mathrm{C}$ & $\mathrm{T} 1$ & $\mathrm{~T} 2$ & $\mathrm{~T} 3$ & $\mathrm{~T} 4$ & \\
\hline \hline Fatty acid composition, \% & & & & & & \\
$\quad$ Myristic acid & 1.34 & 1.43 & 1.53 & 1.39 & 1.58 & 0.28 \\
$\quad$ Plamitic acid & 24.68 & 24.92 & 24.34 & 24.51 & 24.34 & 1.08 \\
$\quad$ Palmitoleic acid & $2.76^{\mathrm{b}}$ & $2.84^{\mathrm{ab}}$ & $2.89^{\mathrm{ab}}$ & $2.67^{\mathrm{b}}$ & $3.14^{\mathrm{a}}$ & 0.41 \\
$\quad$ Stearic acid & 11.09 & 11.27 & 11.04 & 11.36 & 11.02 & 0.62 \\
$\quad$ Oleic acid & 43.17 & 43.28 & 43.95 & 43.35 & 42.38 & 1.56 \\
$\quad$ Linoleic acid & 15.27 & 14.32 & 14.28 & 14.67 & 15.34 & 1.45 \\
$\quad$ Linolenic acid & 0.53 & 0.67 & 0.76 & 0.68 & 0.69 & 0.02 \\
$\quad$ Arachidonic acid & $1.06^{\mathrm{b}}$ & $1.27^{\mathrm{ab}}$ & $1.21^{\mathrm{ab}}$ & $1.37^{\mathrm{ab}}$ & $1.51^{\mathrm{a}}$ & 0.08 \\
\hline Saturated fatty acid (SFA) & 37.11 & 37.62 & 36.91 & 37.26 & 36.94 & 1.32 \\
Unsaturated fatty acid (USFA) & 62.89 & 62.38 & 63.09 & 62.73 & 63.06 & 1.16 \\
Essential fatty acid & $16.86^{\mathrm{ab}}$ & $16.26^{\mathrm{b}}$ & $16.25^{\mathrm{b}}$ & $16.72^{\mathrm{ab}}$ & $17.54^{\mathrm{a}}$ & 0.68 \\
USFA/SFA & 1.69 & 1.66 & 1.71 & 1.68 & 1.71 & 0.29 \\
SFA/USFA & 0.27 & 0.26 & 0.26 & 0.27 & 0.28 & 0.02 \\
\hline
\end{tabular}

\footnotetext{
1) Twelve LD were analyzed in each treatment.

${ }^{2)}$ The basal diet was substituted with fermented mushroom (F. velutipes) by-products: C, no substitution; T1, 10\%; T2, 30\%; T3, 50\% and T4, $70 \%$.

${ }^{\mathrm{a}, \mathrm{b}}$ Values in the same row with different superscripts differ at $\mathrm{P}<0.05$.
} 
Chu et. al. ; Fermented Mushroom By-product on Pork Quality

Table 5. The effects of the fermented mushroom by-products diet on the amino acid concentration in longissimus dorsi (LD) of Berkshire pigs ${ }^{1)}$

\begin{tabular}{|c|c|c|c|c|c|c|}
\hline \multirow{2}{*}{ Item } & \multicolumn{5}{|c|}{ Treatment $^{2)}$} & \multirow{2}{*}{ SEM } \\
\hline & $\mathrm{C}$ & $\mathrm{T} 1$ & $\mathrm{~T} 2$ & $\mathrm{~T} 3$ & $\mathrm{~T} 4$ & \\
\hline Essential amino acid, \% & 9.73 & 9.78 & 9.78 & 9.75 & 9.75 & 0.11 \\
\hline Arginine & 1.27 & 1.23 & 1.25 & 1.21 & 1.26 & 0.08 \\
\hline Histidine & 0.83 & 0.83 & 0.89 & 0.90 & 0.91 & 0.05 \\
\hline Isoleucine & 1.03 & 1.04 & 1.04 & 0.98 & 0.96 & 0.06 \\
\hline Leucine & 1.63 & 1.64 & 1.54 & 1.56 & 1.56 & 0.08 \\
\hline Lysine & 1.69 & 1.79 & 1.80 & 1.82 & 1.83 & 0.07 \\
\hline Methionine & 0.45 & 0.44 & 0.48 & 0.49 & 0.42 & 0.02 \\
\hline Phenylalanine & 0.83 & 0.82 & 0.82 & 0.80 & 0.81 & 0.04 \\
\hline Threnonine & 0.87 & 0.81 & 0.81 & 0.83 & 0.84 & 0.04 \\
\hline Valine & 1.13 & 1.18 & 1.15 & 1.16 & 1.16 & 0.07 \\
\hline Unessential amino acid, \% & 9.08 & 9.03 & 9.05 & 9.12 & 9.26 & 0.16 \\
\hline Alanine & 1.09 & 1.05 & 1.06 & 1.06 & 1.09 & 0.08 \\
\hline Aspartic acid & 1.80 & 1.81 & 1.72 & 1.78 & 1.80 & 0.09 \\
\hline Cystine & 0.15 & 0.20 & 0.21 & 0.18 & 0.15 & 0.01 \\
\hline Glutamic acid & 3.14 & 3.12 & 3.15 & 3.17 & 3.16 & 0.12 \\
\hline Glysine & 0.84 & 0.82 & 0.80 & 0.86 & 0.95 & 0.02 \\
\hline Proline & 0.73 & 0.75 & 0.73 & 0.76 & 0.76 & 0.01 \\
\hline Serine & 0.71 & 0.66 & 0.71 & 0.67 & 0.69 & 0.01 \\
\hline Tyrosine & 0.62 & 0.62 & 0.67 & 0.67 & 0.66 & 0.01 \\
\hline Total amino acid, \% & 18.81 & 18.81 & 18.83 & 18.87 & 19.01 & 2.84 \\
\hline
\end{tabular}

1) Twelve LD were analysed in each treatment.

2) The basal diet was substituted with fermented mushroom (F. velutipes) by-products: C, no substitution; T1, 10\%; T2, 30\%; T3, 50\% and T4, $70 \%$.

Table 6. The effects of the fermented mushroom by-products diet on the sensory evaluation ${ }^{1)}$ in longissimus dorsi (LD) of Berkshire pigs ${ }^{2}$

\begin{tabular}{lcccccc}
\hline \multirow{2}{*}{ Item } & \multicolumn{7}{c}{ Treatment $^{3}$. } & \multirow{2}{*}{ SEM } \\
\cline { 2 - 5 } & $\mathrm{C}$ & $\mathrm{T} 1$ & $\mathrm{~T} 2$ & $\mathrm{~T} 3$ & $\mathrm{~T} 4$ & \\
\hline \hline Cooked meat & & & & & & 0.68 \\
Color & 5.33 & 5.13 & 5.47 & 5.33 & 5.38 & 0.67 \\
Aroma & 6.00 & 6.00 & 6.40 & 6.50 & 6.04 & 0.77 \\
Taste & 6.50 & 6.46 & 6.67 & 6.90 & 6.85 & 1.33 \\
Tenderness & 6.17 & 6.00 & 6.00 & 6.33 & 6.23 & 0.74 \\
Texture & 6.50 & 6.47 & 6.67 & 6.83 & 6.92 & 0.91 \\
Juiciness & 6.67 & 6.73 & 6.83 & 6.83 & 6.85 & 1.35 \\
Acceptability & 6.92 & 6.67 & 6.63 & 7.00 & 6.92 & \\
\hline
\end{tabular}

${ }^{1)}$ Sensory evaluation was scored on 9 point scale based on 1 (extremely bad or slight) to 9 (extremely good or much).

${ }^{2)}$ Twelve LD were analyzed in each treatment.

3) The basal diet was substituted with fermented mushroom (F. velutipes) by-products: C, no substitution; T1, 10\%; T2, 30\%; T3, 50\% and T4, $70 \%$. 


\section{DISCUSSION}

Chu et al. (2012) studied the effects of a fermented mushroom $(F$. velutipes $)$ by-products diet on the growth performance and carcass traits in growing-fattening Berkshire pigs. According to their results, $\mathrm{CP}$ concentration and total calories in the fermented diet increased at the end of fermentation $(5 \mathrm{~d})$ compared with those at the initial fermentation day $(0 \mathrm{~d})$. The fermented mushroom by-products diet decreased ADG, feed efficiency, and carcass weight, and improved carcass grades and ratio of high grade (1 plus 2 grades) due to its low energy levels. Although a diet of fermented mushroom by-products decreases growth performance and feed efficiency, it improves carcass grade in Berkshire pigs (Chu et al., 2012).

This experiment also indicated that the supplementing with $<50 \%$ fermented mushroom by-products increased $\mathrm{pH}$, and decreased cooking loss of LD in fattening Berkshire pigs. The $\mathrm{pH}$ of LD increases with a fermented apple diet (Lee et al., 2009). The $\mathrm{pH}$ of LD decreased with a fermented oyster mushroom by-product diet (Song et al., 2007) and fermented persimmon shell diet (Kim et al., 2006). A high level of a soluble carbohydrate diet increases glycogen concentration and decreases $\mathrm{pH}$ at $24 \mathrm{~h}$ post-slaughter in muscles (Gallway et al., 1977). The high fiber level in the fermented mushroom by-product diet decreased $\mathrm{pH}$ of the $\mathrm{LD}$ in present experiment. The $\mathrm{pH}$ of $\mathrm{LD}$ increases by suppressing lactate accumulation due to low concentrations of glycogenand creatine phosphate (Hamm, 1960). Rosenvold (2003) reported that high fat and low soluble carbohydrate affects the $\mathrm{pH}$ at $45 \mathrm{~min}$ after slaughter but not at $48 \mathrm{~h}$ after slaughter. Kang et al. (2010) reported that a supplemental high carbohydrate-low fat fermented diet decreases cooking loss due to changes in glycolysis at $24 \mathrm{~h}$ post-slaughter in pigs. Therefore, the $\mathrm{pH}$ and cooking loss of meat may be affected by the fermented mushroom byproduct diet.

Our experiment also showed that the fermented mushroom by-product diet decreased CIE L*(lightness), CIE $\mathrm{a}^{*}$ (redness), and CIE $\mathrm{b}^{*}$ (yellowness) of meat color and increased CIE $a^{*}$ and CIE $b^{*}$ of backfat color. Kang et al. (2010) reported that a high carbohydrate-low fat fermented diet increases lightness and redness, but does not affect yellowness in fattening pigs. Meat color is influenced greatly by a variety of factors, such as animal (breed, sex and age), environment (feeding, transporting and slaughter condition), processing (storing time, temperature condition, and etc.), particularly fresh meat color is influenced by the initial $\mathrm{pH}$ and temperature of slaughter processing (Lindahl et al., 2006). Moreover, the lightness of meat decreases by controlled posthumous processing due a diet low in soluble carbohydrate fed to fattening pigs (Tikk et al., 2006).

Our experiment indicated that the $70 \%$ fermented mushroom by-product diet increased the composition of palmitoleic acid and arachidonic acid in LD of fattening Berkshire pigs. Song et al. (2007) reported that a diet of fermented oyster mushroom by-product increased the composition of palmitoleic acid and arachidonic acid in the LD of Berkshire pigs. Moreover, some researchers have reported that fatty acid composition of meat can be improved by diet (French et al., 2000; Hsia and Lu, 2004; Nuernberg et al., 2005).

The fermented mushroom by-product diet did not affect amino acid composition of the LD or the sensory evaluation of cooked meat in fattening Berkshire pigs. Kang et al. (2010) reported that a fermented high carbohydrate-low fat diet using agro by-products does not affect amino acid composition of LD in agreement with the results from this study. A sensory evaluation is an important factor to judge meat quality because of its importance to the consumer. The sensory evaluation of cooked LD meat improves by red clover silage (Jonsall et al., 2000), fermented persimmon shell (Kim et al., 2006) and fermented apple diets (Lee et al., 2009). Our results showed that the sensory evaluation of cooked meat was not affected by the fermented mushroom by-product diet in fattening Berkshire pigs.

\section{CONCLUSION}

Although a diet of fermented mushroom by-products decreases growth performance and feed efficiency, it improves carcass grade (Chu et al., 2012). In this study, the fermented mushroom ( $F$. velutipes $)$ by-product diet did not affect chemical composition, amino acid composition of the LD, or a sensory evaluation of cooked meat. However, it clearly increased the $\mathrm{pH}$, backfat color(redness and yellowness) and essential fatty acid composition, and decreased cooking loss, WBSF of fresh meat, and meat color (lightness, redness and yellowness) of LD in fattening Berkshire pigs. Further investigations are required to clarify the effects of a fermented mushroom by-product diet on the mechanisms of meat quality in Berkshire pigs. 


\section{ACKNOWLEDGMENTS}

This work was presented as a part of a Master's dissertation by Jeong-Mo Yang. This work was supported by the Priority Research Centers Program through the National Research Foundation of Korea (NRF) funded by the Ministry of Education, Science, and Technology (2009-0093813) and Cooperative Research Program for Agriculture Science \& Technology Development (Project No.PJ0077672011) by the Rural Development Administration (RDA), Republic of Korea.

\section{REFERENCES}

Bae, J. S., Kim, Y. I., Jung, S. H., Oh, Y. G. and Kwak, W. S. 2006. Evaluation on feed-nutritional value of spent mushroom (Pleurotus osteratus, Pleurotus eryngii, Flammulina velutupes) substrates as a roughage source for ruminants. Kor. J. Anim. Sci. Technol. 48:237-246.

Chu, G. M., Yang, J. M., Kim, H. Y., Kim, C. H. and Song, Y. M. 2012. Effects of fermented mushroom (Flammulina velutipes) by-product diets on growth performance and carcass traits in growing-fattening Berkshire pigs. Anim. Sci. J. 83: $55-62$.

Duncan, D. B. 1955. Multiple range and multiple F tests. Biomet. 11: 1 .

French, P., Stanton, C., Lawless, F., O’Riordan, E. G., Monahan, F. J., Caffrey, P. J. and Moloney, A. P. 2000. Fatty acid composition, including conjugated linoleic acid of intramuscular fat from steers offered grazed grass, grass silage, or concentrate-based diets. J. Anim. Sci. 78:2849-2855.

Gallway, W. J., Tarrant, P. V. and McMahon, P. 1977. Pig-meat quality and yield in relation to pre-slaughter sugar-feeding. Irish J. Food Sci. Technol. 1:71-77.

Gao, L., Yang, H., Wang, X., Huang, Z., Ishii, M., Igarashi, Y. and Cui, Z. 2008. Rice straw fermentation using lactic acid bacteria. Biores. Technol. 99:2742-2748.

Hamm, R. 1960. Biochemistry of meat hydration. Adv. Food Res. 10:355.

Honikel, K. O. 1998, Reference methods for the assessment of physical characteristics of meat. Meat Sci. 49:447-457.

Hsia, L. C. and Lu, G. H. 2004. The effect of high environmental temperature and nutrient density on pig performance, conformation and carcass characteristics under restricted feeding system. Asian-Aust. J. Anim. Sci. 17:250-258.

Jonsall, A., Johansson, L. and Lundstron, K. 2000. Effects of red clover silage and $\mathrm{RN}$ genotype on sensory quality of prolonged frozen stored pork (M. Longissimus doris). Food Quality Prefer. 11:371-376.

Kang, S. N., Song, Y. M., Kim, C. W., Kim, T. W., Chu, G. M., Yang, B. S., Jin, S. K. and Kim, I. S. 2010. Effect of feeding high carbohydrate-low fat fermented feed on the meat quality characteristics in finishing pigs. Kor. J. Food Sci. Anim. Res. 30:826-832.

Kim, H. Y., Song, Y. M., Jin, S. K., Kim, I. S., Kang, Y. S., Lee, S. D., Chowdappa, R., Ha, J. H. and Kang, S. M. 2006. The effect of change in meat quality parameters on pig longissimus doris muscle by the addition of fermented persimmon shell diet. Asian-Aust. J. Anim. Sci. 19:286-291.

Kim, Y. I., Bae, J. S., Jung, S. H., Ahn, M. H. and Kwak, S. K. 2007. Yield and physicochemical characteristics of spent mushroom(Pleurotus ryngii, Pleurotus osteratus and Ammulina velutipes) substrates according to mushroom species and cultivation types. Kor. J. Anim. Sci. Technol. 49:79-88.

Kwak, W. S., Jung, S. H. and Kim, Y. I. 2008. Broiler litter supplementation improves storage and feed-nutritional value of sawdust-based spent mushroom substrates. Biores. Technol. 99: 2947-2955

Kwak, W. S., Kim, Y. I., Seok, J. S., Oh, Y. K. and Lee, S. M. 2009. Molasses and microbial inoculants improve fermentability and silage quality of cotton waste-based spent mushroom substrate. Biores. Technol. 100:1471-1473.

Lee, S. D., Kim, H. Y., Jung, H. J., Ji, S. Y., Chowdappa, R., Ha, J. H., Song, Y. M., Park, Y. M., Park, J. C., Moon, H. K. and Kim, I. C. 2009. The effect of fermented apple diet supplementation on the growth performance and meat quality in finishing pigs. Anim. Sci. J. 80:79-84.

Lindahl, G., Enfalt, A. C., Andersen, H. J. and Lundstrom, K. 2006. Impact of $\mathrm{RN}$ genotype and storage time on colour characteristics of the pork muscles longissimus doris and semimembranosus. Meat Sci. 74:746-755.

Meilgaard, M., Civille, G. V. and Carr, B. T. 1991. Affective tests: Consumer tests and in-house panel acceptance tests. In: Sensory evaluation techniques. 3rd ed., CRC Press Inc, Boca Ranton, FL, pp. 211-222.

Nuernberg, K., Fischer, K., Nuernberg, G., Kuechenmeister, U., Klosowska, D., Eliminowska-Wenda, G., Fiedler, I. and Ender, K. 2005. Effects of dietary olive and linseed oil on lipid composition, meat quality, sensory characteristics and muscle structure in pigs. Meat Sci. 70:63-74.

Rosenvold, K., Esse n-Gustavsson, B. and Andersen, H. J. 2003. Dietary manipulation of pro- and macroglycogen in porcine skeletal muscle. J. Anim. Sci. 81:130-134. 
Song, Y. M., Lee, S. D., Chowdappa, R., Kim, H. Y., Jin, S. K. and Kim, I. S. 2007. Effects of fermented oyster mushroom (Pleurotus ostreats) by-product supplementation on growth performance, blood parameters and meat quality in finishing Berkshire pigs. Anim. 1:301-307.

Stanton, C., Lawless, F., Kjellmer, G., Harrington, D., Devery, R., Connolly, J. F. and Murphy, J. 1997. Dietary influences on bovine milk cis-9, tran-11-conjugated linoleic acid content. J. Food Sci. 62:1083-1086.

SAS. 1999. User's Guide: Statistics Version 8 ed. SAS Institute, Cary, NC.

Tikk, K., Tikk, M., Karlsson, A. H. and Andersen, H. J. 2006.
The effect of a muscle-glycogen-reducing finishing diet on porcine meat and fat colour. Meat Sci. 73:378-385.

Way, P. and Hanahan, D. J. 1964. Characterization and quantification of red cell lipids. J. Lipid Res. 5:318-328.

Williams, B. C., McMullan, J. T. and McCahey, S. 2001. An initial assessment of spent mushroom compost as a potential energy feedstock. Biores. Technol. 79:227-230.

Wyszcecki, G. and Stiles, W. S. 1982. Color science. Concepts and method, quantitative data and formula. New York, John Wiley.

(Received Feb. 10, 2012; Revised May 24, 2012; Accepted Jun. 9, 2012) 